\title{
SMO Gene Mutation
}

National Cancer Institute

\section{Source}

National Cancer Institute. SMO Gene Mutation. NCI Thesaurus. Code C124793.

A molecular genetic abnormality that refers to the mutation of the SMO gene located on chromosome 7q32.3. 